\title{
Pengaruh Pemberian Gel Lidah Buaya (Aloe vera) Terhadap Jarak Pinggir Luka pada Tikus Wistar
}

\author{
Farhan Nazir ${ }^{1}$, Asril Zahari², Eliza Anas ${ }^{3}$
}

\begin{abstract}
Abstrak
Luka adalah hilang atau rusaknya sebagian jaringan tubuh yang menyebabkan gangguan kontinuitas jaringan tersebut. Lidah buaya telah digunakan sebagai pengobatan tradisional diberbagai kebudayaan diseluruh dunia. Tujuan penelitian ini adalah untuk melihat pengaruh gel lidah buaya terhadap penyembuhan luka, yang ditinjau dari jarak pinggir luka. Penelitian ini merupakan penelitian eksperimental dengan post-test only control group design. Subjek penelitian terdiri dari 24 ekor tikus Wistar betina yang dibagi menjadi empat kelompok; satu kelompok kontrol dan tiga kelompok perlakuan. Kelompok kontrol diberikan $\mathrm{NaCl}$ fisiologis sebagai terapi luka sedangkan kelompok perlakuan diberikan gel lidah buaya dengan berbagai frekuensi pemberian. Hasil penelitian menunjukkan bahwa pemberian olesan gel lidah buaya tidak memberikan pengaruh yang signifikan terhadap penyembuhan luka. Pada setiap variabel jarak pinggir luka terlihat bahwa kelompok kontrol memiliki hasil penyembuhan luka yang lebih baik dari hari ke hari. Secara umum, pada tujuh hari pertama (fase hemostasis dan inflamasi) ukuran jarak pinggir luka memiliki perbedaan yang bermakna $(p<0,05)$. Pada hari-hari selanjutnya pada fase proliferasi, ukuran jarak pinggir luka secara umum tidak memiliki perbedaan yang bermakna ( $>0,05)$. Kesimpulan penelitian ini adalah pemberian gel lidah buaya tidak lebih efektif dibandingkan $\mathrm{NaCl}$ fisiologis terhadap penyembuhan luka yang ditinjau dari jarak pinggir luka.
\end{abstract}

Kata kunci: gel lidah buaya, penyembuhan luka, jarak pinggir luka

\section{Abstract}

A wound is a laceration or break in the living tissue which causes continuity damage within the tissue. Aloe vera has been used for traditional medication in many cultures all over the world. The objective of this study was to see the effect of Aloe vera gel on wound healing based on the wound edge distance. This research was experimental with post-test only control group design. Twenty-four female Wistar rats were divided into four groups; one control group and three treatment groups. The control group was given fisiological $\mathrm{NaCl}$ solution for open wound therapy and treatments groups were given Aloe vera gel with varying frequencies of application. The results shows that Aloe vera wasn't have a significant effect on wound healing. In each variable of wound edge distance, results show that the control group heals better from day to day. As seen in the general, in the seven first days (hemostatis and nflammation phase), the distance of wound edge was significantly different $(p<0.05)$. In the following days (proliferation phase), the distance of wound edge generally wasn't significantly different $(p>0.05)$. The conclusion of this study is Aloe vera gel isn't effective when compared to fisiologic $\mathrm{NaCl}$ solution in healing the wound, based on the wound edge distance.

Keywords: Aloe vera gel, wound healing, wound edge distance

Affiliasi penulis: 1. Pendidikan Dokter FK UNAND (Fakultas Kedokteran Universitas Andalas Padang), 2. Bagian IImu Bedah FK UNAND/RSUP Dr. M Djamil Padang, 3. Bagian Biologi FK UNAND Korespondensi:Farhan Nazir, Email: farhannazir41@gmail.comTelp: 081375226443

\section{PENDAHULUAN}

Kulit memiliki peranan yang sangat penting bagi manusia mulai dari peran estetika hingga untuk menjaga kelangsungan hidup sehingga menjaga 
kontinuitasnya menjadi hal yang penting. ${ }^{1-3}$

Gangguan pada kulit yang sering dihadapi dokter adalah luka. Luka adalah hilang atau rusaknya sebagian jaringan tubuh yang menyebabkan gangguan kontinuitas, sehingga terjadi pemisahan struktur jaringan yang semula normal. Insidennya sendiri cukup sering terjadi pada aktivitas rumah tangga sehari-hari seperti tertusuk, ataupun tersayat pisau, yang seluruhnya merupakan bentuk luka terbuka. Berdasarkan RISKESDAS tahun 2007, rerata prevalensi cedera luka terbuka sebesar $25,4 \%$ dengan kasus tertinggi pada ibu rumah tangga sebesar 32,2\% akibat terluka benda tajam atau tumpul. Prevalensi cedera luka terbuka untuk Provinsi Sumatera Barat mencapai $27,1 \%$ dengan kelompok usia tertinggi

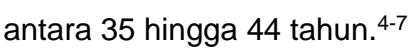

Penyembuhan luka adalah proses perbaikan alami terhadap cedera jaringan dengan melibatkan mediator-mediator inflamasi, sel darah, matriks ekstraseluler, dan parenkim sel. Prosesnya terdiri dari tiga fase; hemostasis dan inflamasi, proliferasi, serta maturasi dan remodelling. Semua jenis trauma yang menyebabkan cedera vaskular akan menginisiasi respon seluler untuk memulai fase hemostasis. Fase ini berlangsung sejak terjadinya luka sampai kira-kira hari kelima. Kontribusi utamanya adalah vaso konstriksi, agregasi platelet dan deposisi fibrin sehingga terbentuk formasi bekuan darah. Sementara itu terjadi reaksi inflamasi berupa eritem, edem, nyeri, dan panas dengan tujuan membawa sel-sel inflamasi ke daerah luka. ${ }^{8-12}$

Pada fase proliferasi terjadi proses proliferasi fibroblast dengan tujuan untuk membentuk kolagen yang akan menautkan tepi luka. Selain itu, juga dibentuk jaringan granulasi. Epitel tepi luka terlepas dari dasarnya dan mengisi permukaan luka. Tempatnya kemudian diisi oleh sel baru yang dibentuk lewat mitosis. Proses ini dimulai sejak akhir fase inflamasi sampai kira-kira akhir minggu ketiga, setelah epitel saling menyentuh dan menutup seluruh permukaan luka. ${ }^{10}$

Pada fase terakhir terjadi penyerapan jaringan berlebih, pengerutan luka dan perupaan kembali jaringan yang terbentuk seperti sediakala. Proses ini berlanjut hingga 12 bulan setelah luka. ${ }^{10,12}$
Saat ini, obat tradisional masih populer digunakan sebagai terapi berbagai penyakit. Salah satu tanaman yang digunakan sebagai obat tradisional adalah lidah buaya (Aloe vera). Lidah buaya termasuk dalam daftar tanaman obat tradisional berdasarkan buku Pemanfaatan Tanaman Obat Departemen Kesehatan Republik Indonesia Edisi ke-3 tahun 1983. Dalam buku tersebut disebutkan salah satu khasiat lidah buaya adalah untuk menyembuhkan luka. Lidah buaya juga telah digunakan selama lebih dari 5000 tahun sebagai obat tradisional pada berbagai kebudayaan seperti Yunani, Mesir, India, Meksiko, Jepang dan Cina sebagai terapi berbagai penyakit seperti radang sendi, jerawat, radang kulit, dan luka. Cara penggunaan lidah buaya adalah dengan mengambil bagian gelnya yang didapatkan dengan menyayat kulitnya lalu dibersihkan hingga lendirnya menghilang. Gel ini dapat digunakan secara oral maupun topikal. ${ }^{9-17}$

Terdapat beberapa bukti yang menjelaskan tentang kegunaan gel ini. Penelitian-penelitian sebelumnya menunjukkan adanya pengaruh gel lidah buaya terhadap penyembuhan luka. Pada gel lidah buaya terdapat substansi alamiah yang terdiri dari enzim, asam amino, dan bahan aktif lain di dalamnya. Substansi tersebut dibutuhkan dalam penyembuhan luka. ${ }^{9,18-19}$

Penelitian Davis, 1989, melaporkan bahwa kelompok tikus yang diterapi dengan gel lidah buaya secara topikal pada luka di punggung menunjukkan perbaikan dalam penyembuhan luka dengan reduksi luka mencapai 50,8\% dibandingkan kelompok kontrol. ${ }^{18}$ Purohit, 2012, menyebutkan bahwa efek penyembuhan luka menggunakan gel lidah buaya menjadi lebih cepat dan lebih baik. ${ }^{20}$ Hajashemi, 2012, menyimpulkan bahwa gel lidah buaya memberikan hasil yang memuaskan pada luka insisi dan luka bakar karena berpotensi sebagai agen anti-inflamasi. ${ }^{21}$ Penelitian Juliane tahun 1991, menunjukkan hasil sebaliknya, disebutkan bahwa gel lidah buaya sebenarnya menunda penyembuhan luka. ${ }^{22}$

Berdasarkan penelitian mengenai efek gel lidah buaya tersebut serta tingginya prevalensi luka terbuka dan penggunaan tanaman obat tradisonal pada masyarakat, maka perlu dilakukan penelitian untuk 
mengetahui sejauh mana pengaruh pemberian gel lidah buaya terhadap penyembuhan luka terbuka, dalam hal ini luka insisi, yang ditinjau pada jarak pinggir lukanya, meliputi panjang, lebar dan luas permukaan luka. Diharapkan nantinya hasil penelitian ini dapat menjadi acuan tambahan terhadap efektivitas gel lidah buaya pada penyembuhan luka, melengkapi hasil penelitian sebelumnya.

\section{METODE}

Jenis penelitian ini adalah eksperimental dengan rancangan post-test only control group design untuk mengetahui pengaruh pemberian gel lidah buaya (Aloe vera) terhadap penyembuhan luka pada tikus Wistar yang ditinjau berdasarkan jarak pinggir luka. Subjek penelitian adalah tikus betina jenis Wistar (Rattus novergicus) berjumlah 24 ekor yang dipisahkan secara acak menjadi satu kelompok kontrol, dan tiga kelompok perlakuan. Jumlah tikus yang dipakai sebagai subjek sesuai dengan penentuan sampel menurut Frederer. ${ }^{23}$

Kriteria inklusi adalah tikus Wistar betina sehat berumur 8-12 minggu pada saat pemilihan sampel dengan berat 170-200 gram. Kriteria ekslusi adalah tikus Wistar sakit dan/atau mati.

Aklimatisasi terhadap hewan dilakukan selama tujuh hari untuk membiasakan hewan pada kondisi percobaan dan diberi makanan standar dan minuman yang cukup. Setiap kelompok sampel diberikan makanan yang sama.

Gel lidah buaya didapatkan dari bagian dalam daun, kemudian dicuci bersih dari getahnya hingga kesat lalu diblender sampai halus dan disimpan dalam lemari pendingin. ${ }^{9}$

Setiap kelompok tikus yang telah dianestesi dengan menggunakan ether dan dicukur bulu pada punggungnya, diberikan paparan luka insisi sepanjang 2-3 cm. Insisi dilakukan hingga fasia otot terlihat dengan menggunakan pisau bedah ukuran 15. Dilakukan penghentian perdarahan terlebih dahulu pada daerah luka dengan balut tekan dan luka dibiarkan selama 24 jam terlebih dahulu sebelum diukur jarak pinggir lukanya.

Kelompok kontrol (A) diberikan larutan $\mathrm{NaCl}$ fisiologis pada daerah luka sebanyak satu kali sehari dan luka dibiarkan terbuka. Pada kelompok perlakuan
I (B) diberikan olesan gel lidah buaya satu kali sehari, kelompok perlakuan II (C) diberikan olesan gel dua kali sehari, dan kelompok perlakuan III (D) diberikan olesan gel tiga kali sehari, luka juga dibiarkan dalam keadaan terbuka. Perlakuan ini diberikan selama dua minggu.

Pengukuran jarak pinggir luka dilakukan pada hari ke-0 (24 jam setelah perlukaan), hari ke-7, dan hari ke-14. Jarak pinggir luka yang diukur adalah panjang (jarak transversal), lebar (jarak longitudinal) dari tiap sisi luka dengan titik acuannya adalah titik terjauh dari tiap sisinya. Luas permukaan luka diukur dengan mengalikan panjang dan lebar luka. Pengukuran jarak pinggir luka menggunakan mikrometer sekrup.

Hasil pengukuran jarak pinggir luka akan dipersentasekan dengan cara mencari selisih jarak pinggir luka pada hari yang diinginkan dengan jarak pinggir luka hari ke-0 lalu dibagi dengan jarak pinggir luka hari ke-0 kemudian dikali 100\%. Setelah perlakuan selesai, seluruh tikus di-euthanasia pada tempat terpisah dari keberadaan hewan lain. ${ }^{23}$

Semua data ditabulasikan menurut kelompoknya, kemudian dihitung rerata (mean) dan simpangan baku (standard deviation) untuk setiap variabel panjang, lebar dan luas permukaan luka kemudian dihitung pula persentasenya. Setelah itu dilakukan uji normalisasi dengan KolmogorovSmirnov. Pada data yang terdistribusi normal kemudian dilakukan uji one-way Anova.

\section{HASIL}

Hewan percobaan yang digunakan adalah tikus Wistar betina dengan umur 8-12 minggu dengan berat badan 170-200 gram. Pada Tabel 1 terlihat bahwa berat badan hewan percobaan tidak berbeda secara signifikan $(p>0,05)$.

Tabel 1. Berat badan hewan percobaan

\begin{tabular}{ccc}
\hline $\begin{array}{c}\text { Kelompok Tikus } \\
\text { Wistar (@=6 ekor) }\end{array}$ & Berat Badan (gram) & \\
\hline A & $196,67 \pm 12,97$ & 0,621 \\
B & $183,17 \pm 9,96$ & 0,686 \\
C & $187,00 \pm 7,07$ & 0,722 \\
D & $181,92 \pm 5,20$ & 0,629 \\
\hline Keterangan: A & : Kelompok kontrol & \\
B & $:$ Kelompok perlakuan I & \\
C & $:$ Kelompok perlakuan II & \\
D & : Kelompok perlakuan III & \\
Data disajikan dalam bentuk Mean \pm SD &
\end{tabular}


Data perbedaan $(p)$ dinyatakan bermakna jika $p \leq 0,05$

Variabel pertama dari jarak pinggir luka yang diukur adalah panjang luka. Titik patokan pengukuran adalah titik terjauh dari kedua sisi longitudinalnya sehingga pada Tabel 2 terlihat hasil pengukuran dan persentase pemendekan panjang luka pada hari ke 0 , 7, dan 14

Tabel 2. Perbandingan ukuran panjang luka $(\mathrm{cm})$

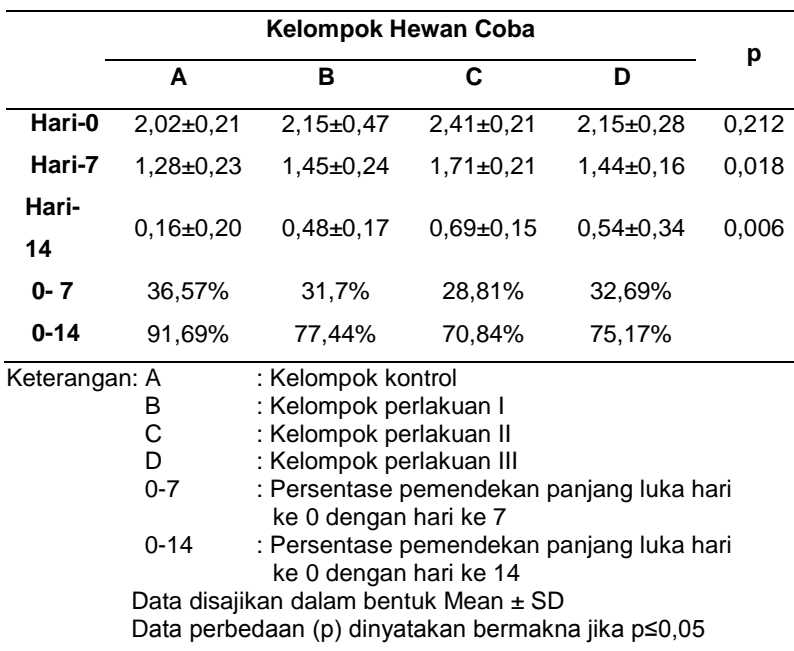

Pada Tabel 2 dapat dilihat ukuran panjang luka pada semua kelompok hewan coba pada hari ke-0 tidak memiliki perbedaan yang bermakna $(p>0,05)$ artinya panjang luka pada setiap hewan coba cenderung sama. Sedangkan pada hari ke-7 dan ke14 terlihat ukuran panjang luka memiliki perbedaan yang bermakna pada semua kelompok hewan coba $(p<0,05)$. Menurut persentase pemendekan panjang luka, terlihat bahwa kelompok A (kontrol) memiliki persentase pemendekan panjang luka yang lebih besar dibandingkan kelompok perlakuan.

Variabel selanjutnya dari jarak pinggir luka yang diukur adalah lebarluka. Titik patokan pengukuran adalah titik terjauh dari kedua sisi transversalnya sehingga pada tabel 3 terlihat hasil pengukuran dan persentase pemendekan lebar luka pada hari ke 0,7 , dan 14 .

Pada Tabel 3 terlihat ukuran lebar luka pada semua kelompok hewan coba pada hari ke-0 memiliki perbedaan yang bermakna $(p<0,05)$ artinya lebar luka pada setiap hewan coba berbeda-beda. Hal ini sudah dapat diketahui sebelumnya dikarenakan perlukaan hanya mengacu pada ukuran panjang saja yang relatif sama sehingga lebar luka yang terbentukpun pasti akan berbeda-beda. Perbedaan ini diantisipasi dengan pengukuran rerata dan persentase penyempitan lebar luka tersebut.

Tabel 3. Perbandingan ukuran lebar luka (cm)

\begin{tabular}{|c|c|c|c|c|c|}
\hline & \multicolumn{4}{|c|}{ Kelompok Hewan Coba } & \multirow{2}{*}{ p } \\
\hline & $\mathbf{A}$ & B & $\mathbf{C}$ & D & \\
\hline Hari-0 & $0,68 \pm 0,13$ & $0,91 \pm 0,17$ & $0,94 \pm 0,16$ & $0,83 \pm 0,04$ & 0,013 \\
\hline Hari-7 & $0,35 \pm 0,13$ & $0,58 \pm 0,13$ & $0,70 \pm 0,11$ & $0,57 \pm 0,07$ & 0,000 \\
\hline $\begin{array}{l}\text { Hari- } \\
14\end{array}$ & $0,03 \pm 0,04$ & $0,09 \pm 0,05$ & $0,18 \pm 0,08$ & $0,19 \pm 0,18$ & 0,057 \\
\hline $0-7$ & $48,4 \%$ & $35,56 \%$ & $24,95 \%$ & $30,78 \%$ & \\
\hline $0-14$ & $94,57 \%$ & $89,95 \%$ & $81,44 \%$ & $77,09 \%$ & \\
\hline Keteran & $\begin{array}{l}\text { yan: A } \\
\text { B } \\
\text { C } \\
\text { D } \\
0-7 \\
0-14 \\
\\
\text { Data d } \\
\text { Data p }\end{array}$ & $\begin{array}{r}\text { :Kelompok } \\
\text { : Kelompok } \\
\text { : Kelompok } \\
\text { : Kelompok } \\
\text { : Persentas } \\
\text { dengan ha } \\
\text { : Persentas } \\
\text { dengan ha } \\
\text { jikan dalam } \\
\text { eedaan }(p) \text { di }\end{array}$ & $\begin{array}{l}\text { ontrol } \\
\text { erlakuan I } \\
\text { erlakuan II } \\
\text { erlakuan III } \\
\text { penyempitar } \\
\text { i ke } 7 \\
\text { penyempitar } \\
\text { i ke } 14 \\
\text { entuk Mean } \\
\text { yatakan bern }\end{array}$ & $\begin{array}{l}\text { lebar luka } \\
\text { lebar luka } \\
\text { SD } \\
\text { lakna jika } p \leq\end{array}$ & $\begin{array}{l}\text { i ke } 0 \\
\text { i ke } 0 \\
05\end{array}$ \\
\hline
\end{tabular}

Berdasarkan Tabel 3, ternyata ukuran lebar luka pada hari ke-14 menunjukkan tidak adanya perbedaan yang bermakna pada ukuran lebar luka ( $>0,05)$, yang artinya pada hari ke-14 ukuran lebar luka pada semua kelompok hewan coba cenderung sama. Meskipun demikian, berdasarkan persentase penyempitan ukuran luka, kelompok $A$ (kontrol) tetap menunjukkan hasil yang lebih baik dibandingkan kelompok perlakuan.

Variabel terakhir dari jarak pinggir luka yang diukur adalah luas permukaan luka. Luasnya didapatkan dari perkalian panjang dengan lebar luka sehingga pada Tabel 4 terlihat hasil pengukuran dan persentase luas permukaan luka.

Tabel 4. Perbandingan luas permukaan luka $\left(\mathrm{cm}^{2}\right)$

\begin{tabular}{|c|c|c|c|c|c|}
\hline & \multicolumn{4}{|c|}{ Kelompok Hewan Coba } & \multirow{2}{*}{$\mathbf{P}$} \\
\hline & A & B & C & D & \\
\hline Hari-0 & $1,37 \pm 0,38$ & $2,02 \pm 0,84$ & $2,27 \pm 0,47$ & $1,79 \pm 0,24$ & 0,052 \\
\hline Hari-7 & $0,44 \pm 0,15$ & $0,86 \pm 0,32$ & $1,20 \pm 0,27$ & $0,83 \pm 0,16$ & 0,000 \\
\hline Hari-14 & $0,11 \pm 0,01$ & $0,05 \pm 0,04$ & $0,13 \pm 0,09$ & $0,15 \pm 0,25$ & 0,284 \\
\hline $0-7$ & $66,69 \%$ & $55,73 \%$ & $53,, 32 \%$ & $36,09 \%$ & \\
\hline 0-14 & $99 \%$ & $97,45 \%$ & $94,23 \%$ & $74,95 \%$ & \\
\hline Keteran & $\begin{array}{c}\text { yan: A } \\
\text { B } \\
\text { C } \\
\text { D } \\
0-7 \\
0-14 \\
\\
\text { Data dis } \\
\text { Data per }\end{array}$ & $\begin{array}{c}\text { : Kelompol } \\
: \text { Kelompol } \\
: \text { Kelompok } \\
: \text { Kelompol } \\
: \text { Persentas } \\
\text { hari ke } 0 \\
: \text { Persentas } \\
\text { hari ke 0c } \\
\text { kan dalam b } \\
\text { daan }(p) \text { dir }\end{array}$ & $\begin{array}{l}\text { ontrol } \\
\text { erlakuan I } \\
\text { erlakuan II } \\
\text { erlakuan III } \\
\text { penyempita } \\
\text { ngan hari k } \\
\text { penyempita } \\
\text { ngan hari ke } \\
\text { ntuk Mean t } \\
\text { atakan bern }\end{array}$ & $\begin{array}{l}\text { luas permuk } \\
7 \\
\text { luas permuk } \\
4 \\
\text { kna jika } p \leq 0 \\
\text { knak }\end{array}$ & $\begin{array}{l}\text { an luka } \\
\text { an luka } \\
5\end{array}$ \\
\hline
\end{tabular}

Pada Tabel 4 terlihat ukuran luas permukaan luka pada semua kelompok hewan coba pada hari ke- 
0 dan ke-14 tidak memiliki perbedaan yang bermakna $(p>0,05)$, artinya luas permukaan luka pada setiap hewan coba cenderung sama pada hari ke-0 maupun pada hari ke-14. Meskipun demikian,berdasarkan persentase penyempitan luas permukaan luka, kelompok A (kontrol) tetap menunjukkan hasil yang lebih memuaskan dibandingkan kelompok perlakuan.

Secara tidak langsung, berdasarkan Tabel 2, 3, dan 4, dapat disimpulkan bahwa pemberian gel lidah buaya tidak memberikan hasil yang lebih memuaskan dibandingkan $\mathrm{NaCl}$ fisiologis dalam hal penyembuhan luka jika ditinjau dari pemendekan panjang luka, serta penyempitan lebar dan luas permukaan luka.

\section{PEMBAHASAN}

Hasil analisis data penelitian ini menunjukkan bahwa pemberian olesan gel lidah buaya tidak memberikan pengaruh yang signifikan terhadap penyembuhan luka yang ditinjau dari jarak pinggir luka dibandingkan dengan $\mathrm{NaCl}$ fisiologis. Pada proses penyembuhan luka, tujuh hari pertama setelah terjadinya luka merupakan fase hemostasis dan inflamasi. Berdasarkan tabel 2, 3, dan 4, secara umum pada tujuh hari pertama, ukuran jarak pinggir luka memiliki perbedaan yang bermakna $(p<0,05)$ pada setiap variabelnya. Sedangkan pada hari-hari selanjutnya, yakni pada fase proliferasi, ukuran jarak pinggir luka secara umum dan dominan tidak memiliki perbedaan yang bermakna $(p>0,05)$ pada setiap variabelnya. ${ }^{10,12}$

Hasil penelitian ini mendukung studi Julliane dan Jeffrey pada tahun 1991, dimana dinyatakan bahwa gel lidah buaya berhubungan dengan penundaan penyembuhan luka. Studinya sendiri dilakukan pada sampel manusia di California yang menjalani laparatomi dan pembedahan sesar. Dalam studinya dijelaskan bahwa kelompok yang diberikan regimen yang tidak mengandung lidah buaya memiliki penyembuhan luka yang lebih memuaskan. Pada studi tersebut juga disebutkan bahwa gel lidah buaya seharusnya tidak digunakan untuk penyembuhan luka karena tidak terlihat manfaat dari efek terapinya. ${ }^{22}$

Studi pendukung hasil penelitian ini adalah studi Watcher pada tahun 1989, yang juga dilakukan di California. Dalam penelitiannya dibandingkan delapan jenis agen topikal yang biasa digunakan dalam penyembuhan luka, dimana salah satunya adalah gel lidah buaya dengan kontrolnya menggunakan $K-Y$ Jelly dan air-exposed healing (luka yang dibiarkan terbuka dan terpapar udara). Penelitian dengan menggunakan sampel babi ini ternyata memberikan hasil yang sangat mengejutkan. Gel lidah buaya ternyata tidak lebih baik dibandingkan dengan $K-Y$ Jelly dan air-exposed healing dalam menyembuhkan luka. Hal ini sangat berbeda dengan hasil penelitian-penelitian lainnya yang menganggap gel lidah buaya berpengaruh signifikan terhadap penyembuhan luka. ${ }^{24}$

Penelitian lain yang membandingkan hidrogel acemanan dengan larutan salin dalam menyembuhkan ulkus dekubitus. Acemanan diketahui sebagai polisakarida utama dalam gel lidah buaya. Hasilnya hidrogel acemanan tidak lebih baik dibandingkan larutan salin dalam menyembuhhkan ulkus dekubitus. Ada juga studi yang menyatakan bahwa gel lidah buaya lebih baik digunakan sebagai regimen terapi pada luka bakar minor dan iritasi kulit serta tidak seharusnya diaplikasikan langsung pada luka terbuka. ${ }^{25-27}$

Salah satu fase dalam proses penyembuhan luka adalah fase hemostasis dan inflamasi yang berlangsung sejak terjadinya luka sampai kira-kira hari kelima. Fase ini bertujuan untuk membawa sel-sel inflamasi ke daerah yang mengalami luka sehingga akan menimbulkan aktivitas seluler untuk memberikan tanda peradangan dan proses fagositosis. Gel lidah buaya mengandung berbagai zat aktif seperti acemanan, giberelin, bradikinin, asam arakidonat, dan polisakarida lainnya yang berperan sebagai agen antiinflamasi. Nantinya hal ini akan berpengaruh terhadap jarak pinggir luka pada hewan coba. Pada kelompok kontrol, fase hemostasis dan inflamasi berjalan tanpa ada intervensi gel lidah buaya memberikan hasil lebih baik pada penyembuhan luka dibandingkan kelompok perlakuan yang mendapatkan intervensi gel lidah buaya pada fase tersebut. Hal ini dapat dilihat dari persentase jarak pinggir luka pada Tabel 2, 3, dan 4 maupun dari tampakan visual luka. Sehingga muncul hipotesis, penyembuhan luka pada kelompok perlakuan mungkin saja akan memberikan hasil yang sama baiknya dengan kelompok kontrol jika fase hemostasis dan inflamasi dilewati tanpa 
intervensi gel. Pada Tabel 2, 3, dan 4 juga dapat dilihat bahwa pada hari ke-0 hingga hari ke-7, semakin sedikit intervensi gel lidah buaya maka secara umum penyembuhan luka semakin baik. ${ }^{10,12,18,28-31}$

Pada hari-hari selanjutnya hingga hari ke-14, dimana fase proliferasi telah menggantikan fase hemostasis dan inflamasi, jarak pinggir luka pada semua kelompok hewan dominan tidak memiliki perbedaan yang bermakna $(p>0,05)$. Hal ini mendukung teori kebanyakan dimana pemberian gel lidah buaya memberikan pengaruh yang signifikan terhadap penyembuhan luka. Pada gel lidah buaya terdapat glukomanan yang merupakan polisakarida utama dan hormon giberelin yang berinteraksi dengan reseptor faktor pertumbuhan fibroblas sehingga akan terjadi stimulasi, aktivasi, dan sintesis kolagen secara signifikan dimana hal ini penting dalam proses kontraksi luka dan menjadi kunci proses penyembuhan luka. Selain itu, gel lidah buaya juga berperan untuk mengubah komposisi kolagen yang nantinya akan meningkatkan persilangan antar seratserat kolagen yang mampu memperkuat jaringan parut yang terbentuk. Disimpulkan bahwa gel lidah buaya mengakselerasi proses kontraksi luka dan meningkatkan kekuatan jaringan parut. ${ }^{10,21,30-32}$

Penelitian Hajashemi pada tahun 2012 membandingkan penyembuhan luka insisi pada tikus Wistar. Kelompok kontrol tidak diberikan terapi apapun, sementara kelompok perlakuan diberikan gel lidah buaya. Hasilnya kelompok perlakuan menunjukkan penyembuhan luka yang signifikan dibandingkan kelompok kontrol. Pada studinya disimpulkan bahwa gel lidah buaya dapat mengakselerasi penyembuhan luka. Selain itu, gel lidah buaya juga berperan sebagai antiinflamasi dan imunomodulator. Serupa dengan hasil penelitian Hajashemi, Purohit pada tahun yang sama membandingkan penyembuhan luka eksisi pada tikus Wistar dimana kelompok kontrol diberikan salep povidon iodin sedangkan kelompok perlakuan diberikan gel lidah buaya. Hasilnya kelompok perlakuan memberikan hasil yang lebih memuaskan. Tetapi pada penelitiannya didapatkan bahwa pada hari ke-0 dan ke-3, ukuran permukaan luka eksisi cenderung sama sementara perbedaan ukuran luka yang bermakna malah terlihat setelah hari ke- 9 penelitian. Secara tidak langsung, penelitiannya mendukung bahwa gel lidah buaya memberikan kontribusi yang besar dalam penyembuhan lukapada fase proliferasi. ${ }^{20,21}$

Penelitian mengenai pengaruh pemberian gel lidah buaya terhadap jarak pinggir luka pada tikus Wistar ini telah dilakukan sesuai dengan prosedur yang seharusnya, namun masih terdapat beberapa keterbatasan dalam pelaksanaannya yaitu perbedaan tingkah laku hewan coba dan lama kontak gel lidah buaya dengan luka yang akan mempengaruhi proses pengukuran jarak pinggir luka dan penyembuhan luka. Tidak adanya mutu gel lidah buaya yang terstandarisasi juga dapat mengakibatkan bias pada penelitian ini. Waktu penelitian yang tergolong singkat juga menjadi keterbatasan penelitian.

\section{KESIMPULAN}

Pemberian gel lidah buaya tidak lebih efektif dibandingkan dengan $\mathrm{NaCl}$ fisiologis terhadap penyembuhan luka yang ditinjau dari jarak pinggir luka. Pada minggu pertama penelitian terdapat perbedaan ukuran jarak pinggir luka yang bermakna dimana kelompok kontrol memberikan hasil yang lebih baik. Pada minggu selanjutnya, secara umum, tidak didapatkan perbedaan ukuran jarak pinggir luka yang bermakna, walaupun kelompok kontrol memiliki persentase yang lebih baik. Semakin sedikit frekuensi pemberian gel lidah buaya pada fase hemostasis dan inflamasi maka hasilnya juga semakin baik. Gel lidah buaya memiliki efek yang sangat baik pada fase proliferasi dan proses kontraksi luka, dimana hal ini berperan penting dalam memperkecil, memendekkan, dan mempersempit ukuran luka.

\section{UCAPAN TERIMA KASIH}

Terima kasih kepada seluruh staf Laboratorium Farmakologi Fakultas Farmasi Universitas Andalas atas bantuan teknis selama penelitian dan kepada seluruh keluarga atas doadan motivasinya.

\section{DAFTAR PUSTAKA}

1. Wasiatmadja SM. IImu penyakit kulit dan kelamin. Edisi ke-3. Jakarta: Fakultas Kedokteran Universitas Indonesia; 2001. 
2. Harahap M. IImu penyakit kulit. Jakarta: Hipokrates; 2000.

3. Robin GB, Tony B. Lecture notes: dermatologi. Edisi ke-8. Jakarta: Erlangga; 2005.

4. Koesoemawati $H$, Huriawati $H$, Ivo NS, Lyana S, Valleria, Suparman W. Kamus saku kedokteran Dorland. Edisi ke-29. Jakarta: EGC; 2002.

5. Karakata S, Bob B. Bedah minor. Medan: Hipokrates; 1991.

6. Departemen Kesehatan. Riset kesehatan dasar; laporan nasional badan penelitian dan pengembangan kesehatan. Jakarta: Depkes RI; 2008.

7. Sinaga M. Risiko kecelakaan kerja di rumah tangga. Medan: Digital Library USU; 2005.hlm. 201-4.

8. Adam JS, Richard AF. Cutaneous wound healing. Massachusetts: Medical Society; 1999.

9. Prawira J. Gambaran histopatologi penyembuhan luka bakar sedang dengan pemberian aloe vera secara topikal pada tikus (skripsi). Padang: Universitas Andalas; 2001.

10. Wim DJ, Sjamsuhidayat R. Buku ajar ilmu bedah. Jakarta: EGC; 2011.

11. Charles FB, Dana KA, Timothy RB, David LD, Jhon $\mathrm{GH}$, Raphael EP, Schawrtz's: manual of surgery. USA: McGraw Hill; 2006.

12. Joan LM, Thomas LW. Clinical in plastic surgery. Kansas: Elsevier Science; 2003.

13. Rohmawati N. Efek penyembuhan luka bakar dalam sediaan gel ekstrak etanol $70 \%$ daun lidah buaya (Aloe vera I.) pada kulit punggung kelinci New Zealand (skripsi). Surakarta: Universitas Muhammadiyah Surakarta; 2008.

14. Setiani T, Fitiana S, Kosterman U. Penerapan penggunaan daun lidah buaya (Aloe vera) untuk pengobatan stomatitis aftosa (sariawan) di Desa Ciburial Kecamatan Cimenyan Kabupaten Bandung Jawa Barat. Bandung: Fakultas Kedokteran Gigi Universitas Padjajaran; 2009.

15. Tukiman. Pemanfaatan tanaman obat keluarga (TOGA) untuk kesehatan keluarga. Medan: Digital Library USU; 2004.hlm.1-8.

16. Langmead LR, Makins RJ, Rampton DS. Alignment pharmacol theraphy: anti-inflammatory effect of Aloe vera gel in human colorectal mucosa in vitro. London: Blackwell Publishing Ltd. 2004;19;521-7.

17. Pandarinathan C, Sajithal GB, Gown Chandrakasan. Influence of Aloe vera on collagen characteristics in healing dermal wounds in rats. Department of Biochemistry, Central Leather Institute. 2005:1-3.

18. Davis RH, Mark GL, Joseph MR, Megan EB. Wound healing, oral and topical activity of Aloe vera. Journal of The American Pediatrics Medical Assoc. 1989;79(11);559-62.

19. Vogler BK, Ernest E. Aloe vera, A Systemic Review of Its Clinical Effectiveness. British Journal of General Practice.1999;823-7.

20. Purohit SK, Solanki R, Soni MK, Mathur V. Experimental evaluation of Aloe vera leaves pulp as topical medicament on wound healing. International Journal of Pharmacological Research Rajashtan; Lachoo Memorial College of Science and Technology; 2012;2:110-1.

21. Hajashemi V, Ghannadi A, Heidari AH. Research in pharmaceutical science: anti-inflammatory and wound healing activities of Aloe littoralis in rats. Isfahan; School of Pharmacy and Pharmaceutical. 2012.hlm.73-8.

22. Juliane MS, Jeffrey SG. Aloe vera dermal wound gel is associated with a delay in wound healing. The American Collage of Obstetricians and Gynecologist. 1991;78(1):115-7.

23. Komite Nasional Etik dan Penelitian Kesehatan RI. Pedoman nasional etik penelitian kesehatan. Jakarta: Depkes RI; 2006.

24. Watcher MA, Ronald GW. The role of topical agents in the healing of full thickness wounds. Journal of Dermatology Surgery Oncology. 1989;15(11):1188-94.

25. David RT, Patricia SG, Kim LR, Teresa T. Advance in wound care. Original Investigation. 1998; 11(6);273-6.

26. Kojo E, Qian H. Critical review in food science and nutrition: Aloe vera; a valuable ingredient for the food. Wuxi: Taylor and Francis Inc. 2004.hlm.91-6.

27. Steven DE. Complementary medicine: Aloe. University of Maryland (diunduh 29 Maret 2013). Tersedia dari: URL: HYPERLINK http://www.umm. edu/altmed/articles/aloe-000221.htm 
28. Josias $\mathrm{HH}$. Molecules; composition and applications of Aloe vera leaf gel. Department of Pharmaceutical Science. Tshwane: Tshwane University of Technology; 2008.hlm.1612-60.

29. Coopoosamy RM, Magwa ML. Traditional use, antibacterial activity and antifungal activity of crude extract of Aloe excels. African Journal of Biotechnology. 2007;6:2406-10.

30. Amar S, Resham V, Saple DG. Aloe vera; a short review. Indian Journal of Dermatology. 2008;53 (4):163-6.
31. Kathi JK, Victoria C. Aloe vera. The Longwood Herbal Task Force and The Center for Holistic Pediatric Education and Research.1999.hlm.1-15.

32. Wandell LC. Aloe vera. Department of Biopharmaceutical. Winchester: University Shenandoah School of Pharmacy; 2005 (diunduh 13 Februari 2013). Tersedia dari: URL: HYPER LINK http://legacy.us.pharmacist.com/oldformat. asp?url=network/files/Alter/apr00aloe.cfm\&pub id= 8\&article id 503 